\title{
All Men Are Welcome: The End of Gender in Boxing
}

\author{
Mischa Merz
}

AFTER NEARLY THIRTY years working as a journalist and author I left my job in newspapers and, a few years later, opened my own boxing gym on the industrial riverfront in Footscray.

Mischa's Boxing Central was born in early 2013.

The last piece of journalism I had published, fittingly, was an interview with Mike Tyson in The Weekly Review, the year before. Over a satellite link, the most dangerous man on the planet and I were in furious agreement that women now had a place in boxing, especially since the only US boxer to medal at the 2012 Olympics was a woman, the middleweight Claressa Shields. We agreed that she deserved more attention than she was getting for this historic achievement. Her victory, he said, had been a slap in the face for all those 'chauvinist pigs'. Mike was now a vegan, and, it seemed, somewhat of a feminist too. Who'd have thought, after chewing off Evander Holyfield's ear and doing time for rape, so much would have changed in the life of Iron Mike.

But things in the fight game have changed a lot too over that time. A few years after the ear bite incident, I had my first boxing fight, inspired by the women I saw on that infamous Tyson undercard, Christy Martin and Andrea DeShong, two extraordinary pioneers of the modern era of women's boxing. At that time it was rare to see women fighting. Dial-up internet was too slow and the stop-start streaming made it frustrating on the rare occasion that you could find anything that wasn't semi pornographic. Occasionally FOX Sport would transmit female 
bouts from overseas on their late-night replays but when they were in control they usually didn't include female bouts in the broadcast, saying no one wanted to watch and in fact viewers would turn off if they saw women fighting. That myth was blown to pieces in 2015 when Holly Holm KOed Ronda Rousey in a UFG fight main event in front of a capacity crowd at Etihad Stadium in Melbourne. But things were different twenty years ago when I went to watch the Tyson fight on the big screen at Crown Casino. I was so thrilled to see the women back then, but I recoiled in horror when I saw Iron Mike's cannibalistic act, as did the rest of the crowd, mostly men in stretch jeans and flannel shirts. But seeing the women was a pivotal moment for me, they seemed to fight with skill and considerable dignity compared to the main event. After all the talk about women being too emotional for the game, it actually looked like the opposite was true.

Over the next two decades I wrote plenty about being a female boxer, breaking taboos and challenging assumptions about what it means to be a woman. But there are many more of us around now in boxing than when I began in the late 1990s so it's not so shocking these days. I've moved on from being the oddity in the gym, the subject of sideways glances and the patronising public discussion. To wit: Should women be allowed to box? To just another one of the crowd. I'm not nearly so weird any more.

But now I am part of another minority cohort - the female boxing coach/gym owner. And even in that I'm not entirely alone. I'm certainly not the first, although I am one of few. I train both men and women in my boxing gym. I never wanted it to be the Fernwood of boxing, making it some kind of safe feminine space. Boxing is neither safe nor feminine. And besides, I always liked training among the boys and enjoyed the camaraderie with them so I wouldn't want to deny other women that chance either. It shouldn't be a segregated sport anyway since it unites people from different backgrounds and genders in ways that are surprising and gratifying, so it is important that the genders mix and share the sport and each other's insights. Even so, I painted the door to my gym pink. And that has had some interesting consequences. Sometimes people ask if men are allowed inside. Sometimes they don't even notice the colour, they're more interested in the location, which is either close to their home or work.

I suspect though, that without even realising it, the pink door can act as a kind of filter. Men who walk in wanting to learn how to fight 
are mostly pretty comfortable with their masculinity. I've had some odd characters bowl through and just as quickly vanish, but not too many who felt the need to wear their testosterone like war paint. I know all too well what that looks like. For a number of years I trained at Melbourne's bikie and bodybuilding mecca, Doherty's Gym in Brunswick where men with tattoos on their necks and bigorexia walked stiffly and slowly around like characters in a bad prison movie. They'd sit and glare between their sets on the bench press, as I sparred in the ring. They looked aggrieved that some squirt of a girl was doing something none of them could ever contemplate doing. I'm glad to be away from the place with its steroid abuse and grunting. Those are the kind of men I never see in my gym, the ones for whom masculinity is a costume - one that's oversized and menacing. I guess that it's the kind of masculinity the men in my gym find troubling too; the parody version they can't relate to. And I'm happy about that. I was tired of the protein powder and spray tans when I decided it wasn't the place for me. The bullet meant for outlaw bikie, Toby Mitchell, that shattered the front window of the place on one of the last days I worked there, was further confirmation. Since then I've been exposed to a much more evolved version of the male human and I suspect, a more authentic version of it.

By and large I'm seeing men, young and old, who are looking for a way to explore their identities rather than manufacture them. If they're rebelling against anything, primarily it's against consumer masculinity, the beefcake and the Red Bull, in favour of something more authentic. And mostly it feels as if they regard my guidance as a kind of neutral thing. It feels like we've arrived in a good place. It's hard to characterise the kind of men that avoid Boxing Central, but they are variously referred to as dickheads, tossers and cockheads. Everyone seems to understand what that means having presumably encountered them elsewhere. I kind of know what they mean; those engaged in a tiresome and tiring pissing competition that don't do much but dampen authenticity.

On another level, I see this new dynamic, of men fighting under a female mentor, as a comprehensive dismantling of the old narrative that questioned the rights to my presence in a boxing gym run by and for men. (And of course I hear the echo of Joyce Carol Oates in her famous proclamation in her essay 'On Boxing' stating that the sport is for men and about men and in fact is men). 
Maybe the true transgressors in this stage of the story, the real taboo breakers, the paradigm shifters, are in fact the men and boys who come to my gym and learn to box with me, a small woman now in her early fifties who has sparred and fought, by now, I'd guess at thousands of rounds. Does that make my gender now truly irrelevant? Or is it significant in different ways, telling me more about others than it is about myself.

When teaching anyone to box, it certainly helps to have been a fighter.

Boxing is hard. It's extremely tough, both emotionally and physically. It's demanding on your mental resources as well because it is highly complex. It's a confounding mix of biomechanics, wizardry and athleticism. It involves geometry, physics, artistry and flair as well as a little mongrel element often referred to as killer instinct. You also need to be extremely fit to execute some of the complex manoeuvres in the ring. So many skills and attributes, so much to think about and absorb. Movement and grace and guts and intelligence and creativity. If I'd known this when I started, getting a rewarding shot of feel-good brain chemicals whenever I hit something, I would have reconsidered. But you don't know what you don't know, right. Everyone's the same. People embark on the journey wide-eyed and enthusiastic, unaware of the emotional intensity and the physical brutality that awaits them. But like Mike Tyson famously said, 'Everyone has a plan, until they get punched in the face.'

And for men and women both, that punch in the face is the true test. They will either retreat from that point on or come back with renewed focus. And that's as it should be. Because it's just the start. And you'll need that resilience again and again. You'll need to fight back from defeat many times. It never ends. So if you can't handle the first shocking impact, chances are it's best to try another sport. Because it can take years to become merely competent, as I have. Not great or outstanding but technically correct and capable of dealing with most scenarios, even being outgunned in terms of speed and height and power. I know how to survive. But I've taken a lot of beatings to get there. Blood noses, sore jaws, black eyes. My neck now crackles and creaks and my nose is not quite straight after a couple of breaks and it's a bit flatter and wider than it was in my twenties. But I manage to remember most people's names out of the hundreds I encounter these days. And I still train every day and spar at least once a week if not more. 
From the outside it seems so simple. Two hands to punch with. But even that is confusing. Left and right. Who really knows the difference? And then leading with your non dominant hand, having to rewire your brain to defy just the first of many instincts that will undermine you if you let them play out, like the impulse to walk, turn away, close your eyes, raise your chin, push your hands out in front of you to fend off the thing that is invading your space.

These instincts will rob you of focus, balance, stability, mobility and the ability to respond.

Perhaps it's our sedentary lifestyle. Our desk bound, one dimensionality. Our slouching passivity. Maybe it's just that most human bodies were only designed to sleep, stand, walk and run and beyond that it's all too confusing. Straightening your arms out to deliver a fist to the target and then retracting them at pace can seem like asking someone to do a cartwheel across the water. Anyway, the test is one of persistence and character not necessarily co-ordination. And that's perhaps the hardest test to pass.

Both men and women are equally capable of undertaking the various rites of passage in boxing but trainers the world over will tell you that women listen more and obey instructions better. A backhanded compliment if ever there was. It seems to celebrate female compliance rather than defiance. But it's my experience too that most women are more 'trainable' than men. Men can often appear to listen but then do not translate nods of understanding into action. But I don't doubt that they do their best. Sometimes I feel like I'm watching the five-year-old version of the man doing what he feels 'fighting' is at some very primal level. And it's almost a force of nature, coming from some deep place - wild and desperate. It can be harder to shape with balance, skill, response times and mindfulness than a woman who comes as a clean slate. It's almost as if the men are sometimes too overcome by emotion and adrenaline to learn. Women's emotions play out differently. They have inner critics who chastise them for failure. Men will more likely punch themselves and grunt 'c'mon' when they mess up while the women will quietly weep at some insurmountable inadequacy.

Both men and women bond after punching each other in the face. But women tend to talk more before they do it while men talk afterwards. A sparring session among men can be a game of silent sizing up before they jump into the ring, while women will try to 
disarm with friendliness and amiability. Maybe she won't hit me too hard if she likes me.

I've met a lot of unsavoury characters too over the years but really boxing has relatively few overall, in the gyms at any rate. Most male boxers have been humbled by defeat and failure often enough to be measured about their capabilities. They know that their power is limited and their ability to dominate is relative and fleeting. It's the hangers-on that can be a problem - those who live vicariously through the man brave enough to step through the ropes. Or those who think a few street fights qualify them to come swaggering into a boxing gym after watching YouTube videos of Kimbo Slice. The pink door doesn't always deter such types, but the culture inside might challenge their illusions. Inside are modern men focused on developing their skills, getting along with each other and the women in the place.

And just like the women, they come from all walks of life.

I've trained plumbers, carpenters and a former US Marine who had done several tours of Afghanistan. I've trained a convicted felon and a Samoan prison officer who cast a mountainous shadow over me as I held pads for him as well as a former Gladiator called Scar. Others have been less dramatic in stature but also quite interesting for other reasons. Among them have been law and medical students as well as a psychology student and sales reps and a butcher's apprentice and pizza chef. They have ranged from less than sixty kilos to more than double that size. They've listened to my instructions, been punched by me and slapped with the pads when they don't hold their hands up.

I've often wondered why they have chosen me. But I don't ask. I'm always gratified when I see the wide eyes of a teenage boy hanging on my every word when I explain to them why they need to keep their chin down and relax their shoulders and turn their knuckles over so they can deliver the punch with sting.

I've sometimes wondered if they come to my gym because they think boxing will be gentler there? They soon discover that while I try to give them some defensive tools before they start sparring, an inevitable consequence is that they will be punched in the face, it's a one hundred per cent certainty. There is no painless way to learn how to fight. The punch will hurt the same in my gym as it will in any other gym. The pink door doesn't prevent pain or exact any greater sympathy. 
If anything, my gender is the elephant in the room. We don't talk about that much so when I started raising it with some of the guys it felt a little too awkward and I didn't persist.

I got vague answers like, 'Well it's hard to find a good coach so when you do you want to stick with them.' And other non-gender specific responses.

I do like all the guys in my gym. They're smart and generous and funny. They make me feel like feminism has made some progress after all. That despite the misogynist online trolls and the lack of equal pay there is still something to celebrate. Some mothers of my generation and younger have raised some pretty decent men and they've clearly been assisted in that task by their male partners in most cases. Evolution has been slow, and a little uneven. But it's happening. I couldn't have opened Mischa's Boxing Central twenty or even ten years ago. The pink door is a sign of the times. But perhaps one actually shouldn't read that much into it.

So I'll leave the final word to Joyce Carol Oates, whose essay 'On Boxing' remains a pretty seminal work on the topic despite the outdated gender stereotypes it contains.

'I can entertain the proposition that life is a metaphor for boxing,' she writes, 'for one of those bouts that go on and on, round following round, jabs, missed punches, clinches, nothing determined, again the bell and again and you and your opponent so evenly matched it's impossible not to see that your opponent is you... Life is like boxing in many unsettling respects. But boxing is only like boxing.' 